\title{
A alma de uma revista
}

António Faria-Vaz*

As cartas aos directores são a alma de uma revista

$\mathrm{P}$ ublicamos neste número da revista uma carta ao director relativa a um artigo publicado no último número. Nesta carta, o Dr. José Mendes Nunes questiona os autores, sobre a evidência clínica de uma determinada recomendação da Direcção Geral de Saúde, a qual sustenta o estudo.

As cartas ao director permitem a troca de opiniões entre os autores e os leitores e, em determinadas circunstâncias, podem mesmo ser tão interessantes

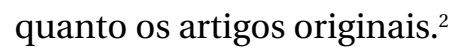

Elas facilitam a discussão, provendo evidência e provas que promovem o debate científico entre os autores dos artigos publicados e os leitores. ${ }^{3}$

As cartas ao director permitem um outro olhar sobre os estudos publicados, uma outra leitura dos métodos, da discussão e dos resultados. No limite, os autores de uma carta ao director, podem mesmo pôr em causa as próprias conclusões desses estudos, emitindo explicações alternativas, através dos seus próprios dados ou mesmo dos dados dos estudos originais. Desta forma, permitem acrescentar conhecimento científico, consentindo de uma forma livre e espontânea que a comunidade científica, a comunidade académica e os leitores de um jornal, dêem uma nova vida ao saber, alterando-o, aprofundando a sua discussão, comentando as implicações na prática clínica diária.

Os comentários a artigos originais, a oportunidade de publicar dados preliminares de estudos em desenvolvimento, relatos de casos clínicos, de acontecimentos adversos ou de séries de casos avultam entre as múltiplas razões que poderão justificar o envio de uma carta ao director.
Segundo alguns autores as cartas ao director podem constituir-se como um dos instrumentos mais preciosos na formação médica, por serem reflexões críticas sobre estudos publicados, exigindo dos autores não só o conhecimento do método científico, como a capacidade de analisar criticamente um estudo científico e enquadrá-lo no contexto da evidência científica e clínica contemporânea. Uma arte, dirão alguns, uma ciência dirão outros. Uma capacidade de sintetizar em poucas palavras o essencial dos aspectos críticos dos estudos publicados, direi eu. Nisto se exige o domínio do científico e a arte de analisar. Um exercício que, não tendo geralmente equiparação, em termos de esforço, a um artigo ou estudo original, significa $40 \%$ do total de manuscritos recebidos pelas mais importantes revistas internacionais, e no JAMA, por exemplo, ascende a cerca de 2000 cartas recebidas anualmente. ${ }^{3}$

As cartas ao director são, portanto, um instrumento e um indicador. Um instrumento, na medida em que nos permite aferir o interesse dos leitores pelos artigos publicados. Um indicador da capacidade de um corpo editorial e de uma comunidade científica, de interagirem através do seu órgão científico.

Assim, desejamos que as cartas ao director sejam um instrumento e uma prática dos médicos de família portugueses, promovendo de uma forma insubstituível a interacção de autores, editores, revisores e leitores. O interesse e a influência dos artigos só têm a ganhar.

Boas leituras

\section{REFERÊNCIAS BIBLIOGRÁFICAS}

1. Glover $S$, editor. Secrets of the press: journalists on journalism. London: Allen Lane; 1999. p. 180.

2. Fernández E, Garcia AM. Sr Director : la importancia de las cartas al director. Gac Sanit 2005;19(5):354-5

3. Foote MaryAnn. Comments on Writing Letters to the Editor. Moving From Duels and Fencing to Belles Lettres. CHEST 2010; 138 (1): 228-30 